\title{
Influence of shareholder equity on trade credit demand: The study of non-financial firms in Pakistan
}

\author{
F. Shah ${ }^{1} \bowtie$, Yu. Liu' ${ }^{1}$, Ya. Shah ${ }^{1}$, F. Shah ${ }^{2}$ \\ ${ }^{1}$ School of Business, Zhengzhou University, Zhengzhou, Henan, China; faizashah55@gmail.com \\ ${ }^{2}$ Shaheed Zulfiqar Ali Bhutto Institute of Science and Technology, Islamabad, Pakistan
}

\begin{abstract}
Relevance. Most small-sized firms have little or no access to credit markets, which is why they prefer equity financing and usually pay higher dividends on this equity. When paying higher dividends, these small-sized debt-free firms continue to build a reputation in the markets. Research objective. The analysis focuses on the trade payables that impact shareholder equity. In Pakistan, most of the businesses are small and middle-sized. Most of the Pakistani SMEs have a low capital structure and these enterprises depend on their daily business needs, so equity financing is their primary source of funding. Data and Methods. The data source for our study is the financial statements of non-financial firms (in total, 156 firms) from the balance Sheet Analysis (BSA) and the Financial Statement Analysis (FSA) published by The State Bank of Pakistan (SBP). The financial statements also provide the data listed by the Pakistan Stock Exchange (PSX). The data cover the period from 2001 to 2017. This study primarily relies on the panel data model. The study applied the methods of descriptive analysis, correlation matrix, common regression model, fixed effect model, random effect model and then the Hausman test was performed to choose the best model. Results. The results of the study indicate a positive and significant relationship between shareholder equity and trade credit demand. Conclusion. Many investors require trade credit as a suitable tool for the growth of shareholders of the company. It is also used in many types of business schemes as the shareholder equity factor plays a role in profit generation through the use of trade credit transactions.
\end{abstract}

\section{KEY WORDS}

trade credit demand, shareholder equity, leverage, growth, Pakistan Stock Exchange (PSX)

\section{FOR CITATION}

Shah F., Liu Yu., Shah Ya., \& Shah F. (2021) Influence of shareholder equity on trade credit demand: The study of non-financial firms in Pakistan. R-economy, 7(1), 61-67. doi: 10.15826/recon.2021.7.1.006.

\section{Влияние акционерного капитала на востребованность торгового кредита: исследование нефинансовых компаний в Пакистане}

\author{
Ф. Шах ${ }^{1}$ Ю. Лиу ${ }^{1}$, Я. Шах ${ }^{1}$, Ф. Шах ${ }^{2}$ \\ ${ }^{1}$ Школа бизнеса, Университет Чжэнчжоу, Чжэнчжоу, Kuтай; faizashah55@gmail.com \\ ${ }^{2}$ Институт науки и технологий Шахида Зульфикара Али Бхутто, Исламабад, Пакистан
}

\begin{abstract}
АННОТАЦИЯ
Актуальность. Большинство малых фирм практически не имеют доступа к кредитным рынкам, поэтому они предпочитают акционерное финансирование и обычно выплачивают более высокие дивиденды. Выплачивая более высокие дивиденды, эти небольшие фирмы, не имеющие долгов, продолжают укреплять репутацию на рынках. Цель исследования. Анализ сосредоточен на торговой кредиторской задолженности, которая влияет на акционерный капитал. В Пакистане большинство предприятий малые и средние. Большинство пакистанских МСП имеют низкую структуру капитала, и эти предприятия зависят от своих повседневных деловых потребностей, поэтому акционерное финансирование является их основным источником финансирования. Данные и методы. Источником данных для нашего исследования является финансовая отчетность нефинансовых фирм (всего 156 фирм) из анализа баланса (BSA) и анализа финансовой отчетности (FSA), опубликованных Государственным банком Пакистана (SBP). Финансовая отчетность также содержит данные с Пакистанской

\section{КЛЮЧЕВЫЕ СЛОВА}

спрос на торговые кредиты, акционерный капитал, левередж, рост, Пакистанская фондовая биржа (PSX) 
фондовой биржи (PSX). Данные охватывают период с 2001 по 2017 г. Это исследование в первую очередь опирается на модель панельных данных. В исследовании применялись методы описательного анализа, корреляционный анализ, общая регрессионная модель, модель с фиксированными эффектами, модель со случайными эффектами, а затем был проведен тест Хаусмана для выбора между ними. Результаты. Результаты исследования указывают на положительную и значимую взаимосвязь между акционерным капиталом и спросом на торговые кредиты. Выводы. Многим инвесторам требуется торговый кредит как подходящий инструмент для роста акционеров компании. Он также используется во многих типах бизнессхем, поскольку фактор акционерного капитала играет роль в получении прибыли за счет использования торговых кредитных операций.

\section{ДЛЯ ЦИТИРОВАНИЯ}

Shah F., Liu Yu., Shah Ya., \& Shah F. (2021) Influence of shareholder equity on trade credit demand: The study of non-financial firms in Pakistan. R-economy, 7(1), 61-67. doi: 10.15826/recon.2021.7.1.006.

\section{Introduction}

The importance of trade credit has been growing in recent decades. As enterprises are trying to make the best use of the available resources, trade credit serves this purpose efficiently. Trade credit provides an input for the future growth of the businesses. Trade credit is a two party agreement, which allow them to exchange goods and services without having to engage into the immediate exchange of money (Ahmed \& Hui, 2016). Despite the changing conditions in trade, there is always a huge demand for trade credit schemes, which remain a profitable business (Shah et al., 2018). Buyers can benefit from trade credits, which has engendered a multitude of business strategies that are successfully implemented all over the world (Kashif et al., 2019).

In their financial decision-making, smalland medium-sized enterprises (SMEs), equity is an important factor in a debt-free market (Byoun $\& \mathrm{Xu}, 2013)$. For the future growth in investors' revenue, lending behavior is important to utilize equity (Emery, 1984). Financial analysts consider these characteristics while assessing the policies and focusing on the procedures of the trade credit (Martínez-Sola et al., 2014). Shareholder equity as a claim after debt payment on the remaining residuals also represents the net value of the company. Most of the investors who feel optimistic about the firms' value focus on equity (Tykvová \& Borell, 2012).

If a firm has a high market value and performs well on the stock market, it tries to remain debtfree by relying on its own equity. Small firms, by issuing shares, pay a high dividend and establish a reputation for shareholders (Anuar \& Chin, 2016). Small firms have lower credibility and struggle to get a credit, which makes equity the main source of funding for these small firms. When a company is formed, investors provide the financing for the purchase of the company's shares. As the company grows, shareholders also have expectations concerning the dividends. As per balance sheet, the profit generated is retained in business and is not paid out as dividends.

SMEs encounter many constraints in getting the external source of financing to run their businesses smoothly (Berger \& Udell, 1998) and (Chod, 2017). The owners of small businesses have always been well informed about their companies as compared to outsiders, such as banks and other financial institutions (Shah Y et al., 2020), (Ahmed, Xiaofeng, \& Abdullah, 2015). Trade credit varies in significance and utility from country to country and also depends on the nature of business (Fairfield \& Yohn, 2001). Therefore, shareholders have a residual claim on company assets and they can bear the additional risk by taking more trade credit to increase their sales. A typical motive for taking a credit is usually the desire to improve product quality (Hill, Kelly, \& Lockhart, 2012). The equity market handles the product that is offered for transactions. In this paper we are going not only to discuss the impact of private equity investment, but also consider the recent policy discussions on credit regulation in Pakistan.

Therefore, our study explores a linkage between shareholder's wealth and the trade credit behavior of non-financial firms in Pakistan. Consequently, as the non-financial firms in the country have low resources, trade credit serves their best interests. The study gives an insight how equity of shareholders can benefit due to the increase in the trade credit demand.

To this end, the objectives of the research are as follows:

- To select the variables affecting SMEs;

- To identify the factors with the strongest influence on SMEs in Pakistan; 
- To analyze the impact of shareholder equity on trade credit demand.

To address these goals, we discuss the variables that influence shareholder equity on trade credit demand. Unlike other similar studies, we examine how equity affects the trade credit of products demand. This research may thus be of use to decision-makers in the sphere of business considering the shareholder equity factor in profit generation through the use of trade credit transactions.

\section{Literature Review}

The agency theory was developed by (Meckling, 1976), who showed that debt increases the value of equity in the volatility of the return on the firm's assets. The agency cost is a term introduced by (Meckling, 1976), which refers to shareholders' opportunity to extract wealth from debt holders by increasing risk. (Stwr C Myers, 1983) showed that in addition to risk shifting, debt can also lead to underinvestment. (Stewart C. Myers \& Majluf, 1984) described the agency conflict that arises between old and new shareholders when managers acting in the interest of the former know more about the firm's value than potential investors. The managers of a firm are better aware of the company's financial strength as compared to outsiders, therefore, they protect the interest of shareholders of the company. For the issuance of new securities, firms prefer equity to overcome the shortage. Managers prefer retained earnings and after that, debt is utilized to generate funds (Hussain, Shahid, \& Akmal, 2016). A firm can maximize equity by increasing debt (Chod, Lyandres, \& Yang, 2018).

The question of why most firms provide trade credit to their customers while receiving credit from their suppliers in the presence of specialized financial intermediaries has puzzled financial economists for several decades. Regarding this question, our work is closer to the studies based on monitoring the advantage of the supplier and those discussing moral hazard. The former approach argues that in the course of their business relationship, the supplier gains superior information about the buyer's credit worthiness (see, e.g., (Ng, Smith, \& Smith, 1999), (Brennan, Maksimovics, \& Zechner, 1988), (Biais \& Gollier, 1997), (Mateut S., Bougheas S., 2006)). The latter focus mostly on the moral hazard faced by the buyer. When product quality is not immediately observable, deferred payment provides the supplier with an incentive to exert effort and serves as a guarantee or a signal of product quality (see, e.g., (Babich \& Kouvelis, 2018), (Kim \& Shin, 2012). According to (Giannetti, Burkart, \& Ellingsen, 2008), the advantage of lending goods over lending cash is that goods are more difficult for an opportunistic borrower to divert for private benefits.

The value of credit transactions relating to operating and contracting costs infers that the equity market perceives frictions that encourage extensions of trade credit. When firms have a different level of debt and equity that has been used in capital structure, managers employ firm strategies to improve the firm's performance (Emery, 1984). Despite the prominent role that the agency theory has played in the research literature, its operational implications have received relatively little attention. One of the few exceptions is (Chod, 2017), who considers a twoproduct firm that chooses the optimal capital structure and, subsequently, invests in productflexible and product-dedicated production capacity. Unlike the previous studies, we examine how equity influences the trade credit of product demand, which distinguishes our study from the work of Chod (Chod, 2017), who does not consider trade credit at all. To increase the wealth of shareholders is the ultimate goal of a company, which maximizes the firm's value and requires more trade credit for the company to be able to perform its functions.

\section{Data and Methodology}

The data source for our study is the financial statements of non-financial firms (in total, 156 firms) from the balance Sheet Analysis (BSA) and the Financial Statement Analysis (FSA) published by The State Bank of Pakistan (SBP). The financial statements also provide the data for the firms listed at the Pakistan Stock Exchange (PSX). The data cover the period from 2001 to 2017. This study primarily relies on the panel data model. The study applied the methods of descriptive analysis, correlation matrix, common regression model, fixed effect likelihood model, fixed effect model, random effect model and in the end we did the Hausman test to choose between the fixed effect model or random-effect model. The fixedeffect model was chosen.

Table 1 shows the distribution of firms across sectors. 63 firms belong to the textile sector, which is the biggest one in the sample. 
Table

Industrial Frequency Distribution

\begin{tabular}{|c|l|c|c|}
\hline No. & \multicolumn{1}{|c|}{ Industry } & Frequency & $\begin{array}{c}\text { Percent- } \\
\text { age (\%) }\end{array}$ \\
\hline D1 & Textile & 63 & 40.38 \\
\hline D2 & $\begin{array}{l}\text { Chemicals, Chemical Prod- } \\
\text { ucts and Pharma. }\end{array}$ & 19 & 12.18 \\
\hline D3 & Manufacturing & 13 & 8.33 \\
\hline D4 & Cement & 10 & 6.41 \\
\hline D5 & $\begin{array}{l}\text { Motor Vehicles, Trailers and } \\
\text { Auto parts }\end{array}$ & 10 & 6.41 \\
\hline D6 & Other food products & 9 & 5.77 \\
\hline D7 & Sugar & 8 & 5.13 \\
\hline D8 & $\begin{array}{l}\text { Paper, Paperboard and } \\
\text { Products }\end{array}$ & 7 & 4.49 \\
\hline D9 & Fuel and Energy Sector & 6 & 3.85 \\
\hline D10 & Mineral products & 3 & 1.92 \\
\hline D11 & Refined Petroleum Products & 3 & 1.92 \\
\hline D12 & $\begin{array}{l}\text { Information, Comm. and } \\
\text { Transport Services }\end{array}$ & 3 & 1.92 \\
\hline D13 & Services Activities & 2 & 1.82 \\
\hline & Total & $\mathbf{1 5 6}$ & $\mathbf{1 0 0}$ \\
\hline
\end{tabular}

The variables used for the analysis are summarized in Table 2. Trade credit demand (TCD) is the ratio of accounts payable to total liabilities. Size (SZ) is the natural log of book value of the assets. Shareholder equity (ET) is the ratio of total assets to total liabilities. Leverage (LEV) is determined by using debt to equity ratio. In addition, fixed assets (FA) are determined by the ratio of fixed assets to total assets. GDP is the log of annual figures of GDP.

Table 2

\section{Variables Used in the Study}

\begin{tabular}{|c|c|c|c|}
\hline Variables & Names & Abbreviations & Formula \\
\hline $\begin{array}{l}\text { Dependent } \\
\text { Variable }\end{array}$ & $\begin{array}{l}\text { Trade } \\
\text { Credit } \\
\text { Demand }\end{array}$ & TCD & $\begin{array}{l}\text { Ratio of AP / } \\
\text { Total Liabilities }\end{array}$ \\
\hline \multirow{5}{*}{$\begin{array}{l}\text { Independent } \\
\text { Variables }\end{array}$} & Size & SZ & $\begin{array}{l}\text { Natural Log of } \\
\text { Book value of } \\
\text { Assets }\end{array}$ \\
\hline & $\begin{array}{l}\text { Shareholder } \\
\text { Equity }\end{array}$ & ET & $\begin{array}{l}\text { Ratio of } \\
\text { Total Assets - } \\
\text { Total Liabilities }\end{array}$ \\
\hline & Leverage & LEV & $\begin{array}{l}\text { Debt / Equity } \\
\text { Ratio }\end{array}$ \\
\hline & Fixed Asset & FA & $\begin{array}{l}\text { Ratio of Fixed } \\
\text { Assets / Total } \\
\text { Assets }\end{array}$ \\
\hline & $\begin{array}{l}\text { Gross } \\
\text { Domestic } \\
\text { Product }\end{array}$ & GDP & $\begin{array}{l}\text { Log of Annual } \\
\text { figures for } \\
\text { GDP }\end{array}$ \\
\hline
\end{tabular}

Source: (Shah et al., 2018)

\section{Research Equation}

The equation for this research is generated according to the variables and looks the following way:

$$
\begin{aligned}
T C D_{i t}= & \alpha_{0}+\beta_{1} S Z_{i t}+\beta_{2} E T_{i t}+\beta_{3} L E V_{i t}+ \\
& +\beta_{4} F A_{i t}+\beta_{5} G D P_{i t}+\varepsilon_{i t}
\end{aligned}
$$

\section{Data Analysis}

For statistical analysis, the software used is E-views 8, which is mostly used in finance and economics. This study contains the panel data regression model. It also computes the descriptive statistics and correlations to check the relation between the variables. After that, we computed the common coefficient model. The assumption of this model is that the data are homogenous, and the equation of this model is as follows:

$$
Y_{i t}=\beta_{0}+\beta_{1} X_{i t}+\ldots+\mu_{i t}
$$

After that, according to the panel data techniques, this study determined the fixed effect redundant likelihood model, which is used to choose between a fixed effect model or randomeffect model.

Table 3

Fixed Redundant Likelihood Model

\begin{tabular}{|l|c|c|c|}
\hline Test Model Effects & Statistic Values & D-F & Prob. \\
\hline F-Cross section & 9.7684 & $(83,603)$ & 0.000 \\
\hline Chi Square & 521.5457 & 80 & 0.000 \\
\hline
\end{tabular}

Source: Authors' computations

As Table 3 illustrates, the model should consider individual effects. Therefore, this study moves to the next step of choosing the best-fit model - the random effect model or fixed-effect model. After that, the Hausman test is used to check the best fit model for this study and results show that the fixed effect model is the most suitable. The assumption of the random effect model is the same as a fixed-effect model, and the intercept is not same for all the cross-sections and time-periods. The function of the random effect model is as follows:

$$
Y_{i t}=\left(\beta_{0}+\mu\right)+\beta X_{1 i t}
$$

The coefficient of a slope can be fixed across all the firms. The function of this model is as follows:

$$
Y_{i t}=\beta_{i t}+\beta_{1} X_{i t}+\ldots+\mu_{i t}
$$

Equation 4 will be continued to present the final results of this study and this study will illustrate the impact of shareholder equity on trade credit demand with the help of a fixed-effect model. 


\section{Results and Discussion}

As Table 4 illustrates, we found an inverse relationship between trade credit demand and firm size, which means that the size of the firms has a significant impact on the trade credit demand. If firms are larger in size, they will hold less credit and vice versa. The results also confirm the tradeoff theory, which demonstrates that larger firms always grab the opportunity to increase the firm's growth and profitability (Abor, 2005; Guizani, 2017). In Pakistan, most firms are family owned, so they induce a greater business diversification. Furthermore, our research evidence shows a positive and significant relationship between trade credit demand and shareholder equity. A higher amount of equity capital indicates that firms will have more opportunities while the risk of going bankrupt is smaller. We found that Pakistani firms mostly belong to middle-sized type, which holds more credit to avail the best opportunity for business growth.

The study also reveals the negative and insignificant relationship between trade credit demand and leverage. It means that most Pakistani firms fear leverage and are reluctant to take extra burden of trade credit. This study also revealed a positive and significant relationship between fixed assets and trade credit demand. It also means that firms want to grab new opportunities of investment in fixed assets and without internal sources they are going to take the trade credit as additional support.

Table 4 above shows the F-stat and P-value, which are 19.251 and 0.0000 . The probability value is less than 0.05 , which means that firm size, shareholder's equity, leverage, fixed assets and gross domestic product have a statistically significant influence on the trade credit demand. It also explains the correctness and consistency of the independent variables to predict the dependent variable and therefore the model is the best fit.

Table 4

Fixed Effect Model of Trade Credit Demand

\begin{tabular}{|l|c|c|}
\hline \multicolumn{1}{|c|}{ Variables } & Coefficients & Prob. \\
\hline C & 0.7371 & 0.0000 \\
\hline SZ & -0.4876 & 0.0004 \\
\hline ET & 0.0085 & 0.0075 \\
\hline LEV & -0.0865 & 0.6543 \\
\hline FA & 0.0345 & 0.0055 \\
\hline GDP & 0.0087 & 0.0433 \\
\hline F-stat & 19.251 & \\
\hline Probability Value & 0.0000 & \\
\hline \multicolumn{2}{|c|}{ Source: Authors' computations } \\
\hline
\end{tabular}

\section{Conclusion}

There is no doubt that the foundation of every company is equity. Shareholders always play a significant role in the construction of a business as the shareholder's wealth is directly linked to the dividend and income of a company. As the company expands, shareholders are concerned about its profits. Small firms follow the same strategy as large firms in relation to profit generation and retention for the growth of their businesses. Small private firms, however, often struggle to raise equity for their business.

While much earlier research has addressed the question of equity financing, the effect of trade credit has recently been discussed in depth with regard to the financing structure of nonfinancial firms. Pakistan is a developing country characterized by the prevalence of small and medium-sized businesses. For small firms, equity is the main source of growth. Investors of these small businesses prefer trade credit as this is the mechanism through which buyers and suppliers can interact and develop their businesses. Both the buyers and suppliers are thus dealing in the same business unit; it fulfills the needs of these investors.

Our results confirm the hypothesis that firm owners are in a stronger position to determine the creditworthiness of their firms. Thus, trade credit is the most suitable external sourcing for investors. We also found evidence of a positive and significant impact of shareholder's wealth on trade financing for their customers. The results indicate a direct and economically significant relationship between shareholder's wealth and trade payables. Moreover, an increase in shareholder's earnings leads to an increase in the demand for trade credit as the source of trade credit becomes more accessible. Therefore, the importance of trade credit is the main external source of funding for small-sized businesses.

The main challenge faced by businesses in a developing country is the lack of investment. Indeed, our research evidence points to the fact that the trade credit demand depends on the pattern of shareholder equity with respect to other factors affecting the market. Pakistani firms have a large amount of shareholder equity, which leads them towards family shareholding ownership. Pakistani firms are usually family-oriented firms so they can quickly generate funds from internal sources or by getting trade credit from their own family and friends and increase their productivity. On the other hand, the firms without access to such type of financial or trade credit support maintain the optimal degree of cash and carry through their rainy days. 


\section{References}

Ahmed, J., \& Hui, X. F. (2016). Investigation of Trade Credit Patterns in Effect with Bank Loan Availability. In: Proceedings of the International Conference on Industrial Engineering and Operations Management, 8-10 March (71173060), 2997-3004.

Ahmed, J., Xiaofeng, H., \& Khalid, J. (2014). Determinants of Trade Credit: The Case of a Developing Economy. European Researcher, 83(9-2), 1694-1706. https://doi.org/10.13187/ er.2014.83.1694.

Ahmed, J., Xiaofeng, H., \& Abdullah, M. (2015). Investigation of causal relationship between trade creditand bank loan during 2008 financial crisis. Journal of Asian Business Strategy, 5(5), 90-98. Retrieved from http://www.aessweb.com/pdf-files/2-190-5(5)2015-JABS-90-98.pdf

Anuar, H., \& Chin, O. (2016). The Development of Debt to Equity Ratio in Capital Structure Model : A case of micro franchising. Procedia Economics and Finance, 35, 274-280. https://doi. org/10.1016/S2212-5671(16)00034-4.

Babich, V., \& Kouvelis, P. (2018). Introduction to the Special Issue on Research at the Interface of Finance, Operations, and Risk Management (iFORM): Recent Contributions and Future Directions. Manufacturing \& Service Operations Management, 20(1), 1-8. https://doi.org/10.1287/ msom.2018.0706.

Berger, A. N., \& Udell, G. F. (1998). The economics of small business finance : The roles of private equity and debt markets in the financial growth cycle. Journal of Banking and Finance, 22, 613-673. Retrieved from https://www.federalreserve.gov/pubs/feds/1998/199815/199815pap.pdf

Biais, B.R. \& Gollier, C. (1997). Trade credit and Credit Rationing. The Review of Financial Studies, 10(4), 903-937.

Brennan, M.J., Maksimovics, V., \& Zechner, J. (1988). Vendor Financing. The Journal of Finance, 43(5), 1127-1141. https://doi.org/10.1111/j.1540-6261.1988.tb03960.x.

Byoun, S., \& Xu, Z. (2013). Why do some firms go debt free? Asia-Pacific Journal of Financial Studies, 42(1), 1-38. https://doi.org/10.1111/ajfs.12009.

Chod, J. (2017). Inventory, Risk Shifting, and Trade Credit. Management Science, 63(10), 3207-3225. https://doi.org/10.1287/mnsc.2016.2515.

Chod, J., Lyandres, E., \& Yang, S. A. (2019). Trade credit and supplier competition. Journal of Financial Economics, 131(2), 484-505. https://doi.org/10.1016/j.jfineco.2018.08.008.

Emery, G.W. (1984). A Pure Financial Explanation for Trade Credit. The Journal of Financial and Quantitative Analysis, 19(3), 271-285. https://doi.org/10.2307/2331090.

Fairfield, P.M., \& Yohn, T.L. (2001).Using Asset Turnover and Profit Margin To Forecast Changes in Profitability. Review of Accounting Studies, 6(4), 371-385. https://doi.org/10.1023/A:1012430513430.

Giannetti, M., Burkart, M., \& Ellingsen, T. (2011). What You Sell Is What You Lend? Explaining Trade Credit Contracts. The Review of Financial Studies, 24(4), 1261-1298. https://doi.org/10.1093/ rfs/hhn096.

Hill, M.D., Kelly, G.W., \& Lockhart, G.B. (2012). Shareholder Returns from Supplying Trade Credit. Financial Management, 41(1), 255-280. https://doi.org/10.1111/j.1755-053X.2012.01198.x.

Hussain, M., Shahid, H., \& Akmal, M. (2016). Effect of Profitability and Financial Leverage on Capita Structure in Pakistan Textile Firms. Arabian Journal of Business and Management Review, 2016 (4), 4-7. https://doi.org/10.4172/2223-5833.1000222.

Jencen M., \& Meckling W. (1976). Theory of the Firm: Managerial Behavior, Agency Costs And Ownership Structure. Journal of Financial Economics, 3(4), 305-360. https://doi.org/10.1016/0304405X(76)90026-X.

Kashif, M., Ahmed, J., Islam, M., \& Gillani, U.F. (2019). Effect of Credit Rating on Trade Credit: Empirical Evidences From Pakistani Non-Financial Firms. Sukkur IBA Journal of Management and Business, 6(1), 1-10. https://doi.org/10.30537/sijmb.v6i1.119.

Kim, S.J., \& Shin, H. S. (2012). Sustaining production chains through financial linkages. American Economic Review, 102(3), 402-406. https://doi.org/10.1257/aer.102.3.402.

Martínez-Sola, C., García-Teruel, P.J., \& Martínez-Solano, P. (2014). Trade credit and SME profitability. Small Business Economics, 42(3), 561-577. https://doi.org/10.1007/s11187-013-9491-y. 
Mateut S., Bougheas S., \& Mizen, P. (2006). Trade credit, bank lending and monetary policy transmission. European Economical Review, 50(3), 603-629. https://doi.org/10.1016/j. euroecorev.2005.01.002.

Myers, S.C., \& Majluf, N.S. (1984). Corporate financing and investment decisions when firms have information that investors do not have. Journal of Financial Economics, 13(2), 187-221. https:// doi.org/10.1016/0304-405X(84)90023-0.

Myers, S.C. (1983). The Capital Structure Puzzle. Journal of Finance, 39(3), 575-592. Retrieved from https://www.studocu.com/en-us/document/university-of-california-davis/economics-101/ essays/the-capital-structure-puzzle-myers/6547719/view

Ng, C.K., Smith, J.K., \& Smith, R.L. (1999). Evidence on the Determinants of Credit Terms Used in Interfirm Trade. Journal of Finance, 54(3), 1109-1129. https://doi.org/10.1111/0022-1082.00138.

Shah, F., Liu, Y., Ahmed, J., Shah, Y., \& Shah, F. (2018). Impact of Risk on Use of Trade Credit: Empirical Evidence from Non-financial Firms in Pakistan. Sukkur IBA Journal of Economics and Finance, 2(1), 55-67.

Shah Y., Liu Y., Shah F., \& Shah F. (2020). Challenges of small- and medium-sized businesses in Pakistan due to COVID-19 pandemic. R-Economy, 6(3), 222-226. https://doi.org/10.15826/ recon.2020.6.3.019.

Tykvová, T., \& Borell, M. (2012). Do private equity owners increase risk of financial distress and bankruptcy? Journal of Corporate Finance, 18(1), 138-150. https://doi.org/10.1016/j. jcorpfin.2011.11.004.

\section{Information about the authors}

Faiza Shah - PhD Researcher, School of Business, Zhengzhou University, Zhengzhou (100 Kexue Ave, Zhongyuan District, Zhengzhou, Henan, China); e-mail: faizashah55@gmail.com

Yumin Liu - Doctor of Business, Associate Professor, School of Business, Zhengzhou (100 Kexue Ave, Zhongyuan District, Zhengzhou, Henan, China); e-mail: zzyuminliu@126.com

Yasir Shah - PhD Researcher, School of Business, Zhengzhou University, Zhengzhou (100 Kexue Ave, Zhongyuan District, Zhengzhou, Henan, China); e-mail: yasirshah_pk@yahoo.com

Fadia Shah - Doctor of Computer Sciences, Assistant Professor, Shaheed Zulfiqar Ali Bhutto Institute of Science and Technology (Shaheed Zulfiqar Ali Bhuto Univeristy, Street 9, Plot 67, H 8/4, Islamabad); e-mail: fadiashah13@yahoo.com

ARTICLE INFO: received November 14, 2020; accepted March 9, 2021

\section{Информация об авторах}

Шах Фаиза - PhD-исследователь, Школа бизнеса, Университет Чжэнчжоу (100 Кексуэ авеню, Чжэнчжоу, Хэнань, 450000, Китай); e-mail: faizashah55@gmail.com

Лиу Юмин - доктор бизнеса, доцент, Школа бизнеса, Университет Чжэнчжоу (100 Кексуэ авеню, Чжэнчжоу, Хэнань, 450000, Китай); e-mail: zzyuminliu@126.com

Шах Ясир - PhD-исследователь, Школа бизнеса, Университет Чжэнчжоу (100 Кексуэ авеню, Чжэнчжоу, Хэнань, 450000, Китай); e-mail: yasirshah_pk@yahoo.com

Шах Фадиа - доктор компьютерных наук, доцент, Институт науки и технологий Шахида Зульфикара Али Бхутто (Стрит \# 09, Плот \# 67, Сектор Н-8/4, Исламабад, Пакистан); e-mail: fadiashah13@yahoo.com

ИНФОРМАЦИЯ О СТАТЬЕ: дата поступления 14 ноября 2020 г.; дата принятия к печати 9 мapma 2021 2. 